\title{
Pengaruh Kepuasan Kerja dan Komitmen Organisasional terhadap Perilaku Kewargaan Organisasional serta implikasinya terhadap Kinerja Pegawai Administrasi Politeknik Komputer Niaga LPKIA Bandung
}

Survei terhadap Akuntan yang bekerja sebagai Auditor pada KAP di Indonesia

\author{
Rahayu S. Purnami \\ Mahasiswa Magister Manajemen Bisnis, Sekolah Pascasarjana Universitas Pendidikan Indinesia \\ rsripurnami@gmail.com
}

\begin{abstract}
Abstrak
Penelitian ini membahas mengenai Pengaruh Kepuasan Kerja dan Komitmen Organisasional terhadap Perilaku Kewargaan Organisasional dan Implikasinya terhadap Kinerja Pegawai Administrasi Politeknik Komputer Niaga LPKIA (PKN-LPKIA) Bandung, yang bertujuan untuk menganalisis dan memperoleh gambaran empiris mengenai pengaruh tingkat kepuasan kerja pegawai terhadap perilaku kewargaan organisasional (OCB), pengaruh tingkat komitmen organisasional terhadap perilaku kewargaan organisasional (OCB), pengaruh tingkat kepuasan kerja pegawai terhadap kinerja, pengaruh tingkat komitmen organisasional terhadap kinerja, pengaruh tingkat perilaku kewargaan organisasional (OCB) terhadap kinerja.

Jenis penelitian yang digunakan adalah jenis metode penelitian eksplanatori atau explanatory research atau penelitian pengujian hipotesis. Data diperoleh melalui kuesioner, wawancara dan observasi di Politeknik Komputer Niaga LPKIA. Hasil pengumpulan data dengan sumber data primer, dengan sampel sebanyak 40 responden dan metode analisis yang digunakan adalah dengan analisis jalur menggunakan Partial Least Square.

Hasil penelitian menunjukkan bahwa tidak terdapat pengaruh positif dari kepuasan kerja terhadap perilaku kewargaan organisasional, terdapat pengaruh positif dari komitmen organisasional terhadap perilaku kewargaan organisasional, tidak terdapat pengaruh positif dari kepuasan kerja terhadap kinerja pegawai, tidak terdapat pengaruh positif dari komitmen organisasional terhadap kinerja pegawai, terdapat pengaruh positif dari perilaku kewargaan organisasional terhadap kinerja pegawai.
\end{abstract}

Kata Kunci : Kepuasan Kerja, Komitmen Organisasional, Perilaku Kewargaan Organisasional, Kinerja

\section{PENDAHULUAN}

Peningkatan jumlah perguruan tinggi swasta menuntut masing-masing institusi perguruan tinggi swasta termasuk Politeknik Komputer Niaga LPKIA (PKN LPKIA) untuk menetapkan strategi yang jitu agar dapat memenangkan persaingan.

Perubahan eksternal semestinya juga diikuti oleh perubahan internal organisasi, agar dapat beradaptasi terhadap lingkungannya. Sumber daya manusia yang berkualitas dan mampu melaksanakan hal lebih dari yang biasanya merupakan faktor terpenting dalam memenangkan persaingan. Partisipasi dari semua karyawan akan tercapai bila terdapat kemauan dari masing-masing individu karyawan. Kemampuan tanpa didukung dengan kemauan, tidak akan menghasilkan apapun. Namun, berdasarkan data yang diperoleh dari sekretariat sumber daya Politeknik Komputer Niaga LPKIA terlihat tingkat perputaran pegawai setiap tahunnya relatif tinggi.

Kemauan karyawan untuk berpartisipasi dalam organisasi, biasanya tergantung pada tujuannya bergabung dengan organisasi. Selain itu kemauan karyawan untuk memberikan sumbangan kepada tempat kerjanya sangat dipengaruhi oleh kemampuan organisasi dalam memenuhi tujuan dan harapan-harapan 
karyawannya. Sehingga dibutuhkan sinergi seluruh pihak di organisasi untuk bekerja sama dan menemukan strategi-strategi kreatif. Hal tersebut dapat tercapai bila para individu dalam organisasi bersedia untuk melakukan tugas yang tidak hanya tercantum dalam deskripsi pekerjaan mereka dan memperlihatkan perilaku "kewargaan yang baik". Perilaku kewargaan organisasional (Organizational Citizenship Behavior-OCB) adalah perilaku pilihan yang tidak menjadi bagian dari kewajiban kerja formal seorang karyawan, namun mendukung berfungsinya organisasi tersebut secara efektif. Seperti membantu individu lain dalam tim, mengajukan diri untuk melakukan pekerjaan ekstra, menghindari konflik yang tidak perlu, menghormati semangat dan isi peraturan, serta dengan besar hati menoleransi kerugian dan gangguan terkait pekerjaan yang kadang terjadi (Robbins, 2008:40).

Organ dan Ryan (1995) menyatakan bahwa kepuasan pegawai, komitmen organisasional, persepsi terhadap keadilan dan persepsi terhadap dukungan pimpinan menjadi faktorfaktor penentu OCB (Podsakoff et al, 2000). Kepuasan kerja seharusnya menjadi faktor penentu utama dari perilaku kewargaan organisasional (OCB) seorang karyawan. Karyawan yang puas tampaknya cenderung berbicara secara positif tentang organisasi, membantu individu lain, dan melewati harapan normal dalam pekerjaan mereka. Selain itu, karyawan yang puas mungkin lebih mudah berbuat lebih dalam pekerjaan karena mereka ingin merespons pengalaman positif mereka (Robbins, 2008:113). Dimensi motivasi, kepuasan kerja, dan komitmen organisasional secara jelas berhubungan dengan OCB (Luthans, 2006:251).

Kelangsungan hidup suatu perusahaan salah satunya tergantung pada kinerja karyawan dalam menyelesaikan tugasnya. Kinerja merupakan perilaku nyata yang ditampilkan setiap orang sebagai prestasi kerja yang dihasilkan oleh karyawan sesuai dengan perannya dalam perusahaan. Pencapaian tujuan perusahaan menjadi kurang efektif bila banyak karyawan yang tidak berprestasi. Dan hal ini akan menimbulkan pemborosan bagi perusahaan. Oleh karena itu kinerja karyawan harus benarbenar diperhatikan.

Inti kajian penelitian ini adalah perilaku kewargaan organisasional (Organizational Citinzenship Behavior-OCB). Penelitian ini akan mengkaji tentang pengaruh kepuasan kerja dan komitmen organisasional terhadap perilaku kewargaan organisasi dan implikasinya terhadap kinerja pegawai .

Berdasarkan uraian di atas, secara lebih rinci pokok masalah di atas dapat dirumuskan dalam pertanyaan-pertanyaan berikut ini :

1. Adakah pengaruh tingkat kepuasan kerja terhadap perilaku kewargaan organisasional (OCB) pegawai administrasi Politeknik Komputer Niaga LPKIA?

2. Adakah pengaruh tingkat komitmen organisasional terhadap perilaku kewargaan organisasional (OCB) pegawai administrasi Politeknik Komputer Niaga LPKIA?

3. Adakah pengaruh tingkat kepuasan kerja terhadap kinerja pegawai administrasi Politeknik Komputer Niaga LPKIA?

4. Adakah pengaruh tingkat komitmen organisasional terhadap kinerja pegawai administrasi Politeknik Komputer Niaga LPKIA?

5. Adakah pengaruh tingkat perilaku kewargaan organisasional (OCB) terhadap kinerja pegawai adminitrasi Politeknik Komputer Niaga LPKIA?

Sesuai dengan rumusan masalah, penelitian ini bertujuan untuk menganalisis dan 
memperoleh gambaran empiris mengenai hal-hal sebagai berikut :

1. Pengaruh tingkat kepuasan kerja terhadap perilaku kewargaan organisasional (OCB) pegawai administrasi Politeknik Komputer Niaga LPKIA.

2. Pengaruh tingkat komitmen organisasional terhadap perilaku kewargaan organisasional (OCB) pegawai administrasi Politeknik Komputer Niaga LPKIA.

3. Pengaruh tingkat kepuasan kerja terhadap kinerja pegawai administrasi Politeknik Komputer Niaga LPKIA.

4. Pengaruh tingkat komitmen organisasional terhadap kinerja pegawai administrasi Politeknik Komputer Niaga LPKIA.

5. Pengaruh tingkat perilaku kewargaan organisasional (OCB) terhadap kinerja pegawai administrasi Politeknik Komputer Niaga LPKIA.

\section{KERANGKA PEMIKIRAN DAN HIPOTESIS PENELITIAN}

Lebih dari 20 tahun yang lalu Davis dan Luthans mengusulkan pendekatan social learning pada perilaku organisasi dan lebih dari 15 tahun yang lalu Luthans dan Kreitner menyarankan pendekatan social learning pada modifikasi perilaku organisasi. Social learning menjelaskan bahwa perilaku dapat diterangkan dengan interaksi timbal balik yang berkelanjutan antara faktor kognisi (cognitive), perilaku behavior), dan lingkungan (environment). Albert Bandura menyatakan, "it is largely through their actions that people produce the environmental conditions that affect their behavior in a reciprocal fashion. The experiences generated by behavior also partly determine what a person becomes and can do, which, in turn, affects subsequent behavior" (Luthans, 2002).
Seseorang bisa memiliki ribuan sikap, tetapi perilaku organisasi memfokuskan perhatian pada jumlah yang sangat terbatas mengenai sikap yang berkaitan dengan kerja. Sikap kerja berisi evaluasi positif atau negatif yang dimiliki oleh karyawan tentang aspek-aspek lingkungan kerja mereka. Sebagian besar penelitian dalam perilaku organisasi berhubungan dengan kepuasan kerja, komitmen organisasional dan keterlibatan kerja. (Robbins, 2008)

Kepuasan kerja merupakan derajat atau tingkatan perasaan positif maupun negatif seorang individu terhadap pekerjaannya. Kepuasan kerja merupakan sikap atau respon emosional terhadap tugas seseorang sebagaimana kondisi fisik dan sosial di tempat kerja. Pengukuran kepuasan kerja menurut Job Descriptive Index terdiri dari (1) the work itself (pekerjaan itu sendiri), (2) quality of supervision (kualitas supervisi), (3) relationships with coworkers (hubungan dengan rekan kerja), (4) promotion opportunities (kesempatan promosi), (5) pay (gaji). (Schermerhorn, 2005:143). Pekerjaan itu sendiri yaitu dalam hal di mana pekerjaan memberikan tugas yang menarik, kesempatan untuk belajar, dan kesempatan untuk menerima tanggung jawab. Gaji yaitu sejumlah upah yang diterima dan tingkat dimana hal ini bisa dipandang sebagai hal yang dianggap pantas dibandingkan dengan orang lain dalam organisasi. Kesempatan promosi yaitu kesempatan untuk maju dalam organisasi. Pengawasan atau kualitas supervisi yaitu kemampuan penyelia untuk memberikan bantuan teknis dan dukungan perilaku. Rekan kerja atau hubungan dengan rekan kerja yaitu tingkat di mana rekan kerja pandai secara teknis dan mendukung secara sosial (Luthans, 2006).

Pengertian komitmen organisasional adalah keinginan kuat untuk tetap sebagai anggota organisasi tertentu, keinginan untuk berusaha keras sesuai keinginan organisasi, keyakinan tertentu dan penerimaan nilai dan tujuan organisasi. Dengan kata lain, ini merupakan 
sikap yang merefleksikan loyalitas karyawan pada organisasi dan proses berkelanjutan dimana anggota organisasi mengekspresikan perhatiannya terhadap organisasi dan keberhasilan serta kemajuan yang berkelanjutan. Dikarenakan komitmen organisasional bersifat multidimensi, maka terdapat perkembangan dukungan untuk tiga model komponen yang diajukan oleh Mayer dan Allen. Ketiga dimensi tersebut adalah:

1. Komitmen afektif (affective commitment) adalah keterikatan emosional karyawan, identifikasi, dan keterlibatan dalam organisasi.

2. Komitmen keberlanjutan (continuance commitment) adalah komitmen berdasarkan kerugian yang berhubungan dengan keluarnya karyawan dari organisasi. Hal ini mungkin karena kehilangan senioritas atas promosi atau benefit.

3. Komitmen normatif (normative commitment) adalah perasaan wajib untuk tetap berada dalam organisasi karena memang harus begitu; tindakan tersebut merupakan hal benar yang harus dilakukan. (Luthans 2006:249)

Perilaku kewargaan organisasional (Organizational Citizenship Behavior-OCB) seringkali didefinisikan sebagai perilaku individu yang mempunyai kebebasan untuk memilih, yang secara tidak langsung atau secara eksplisit diakui oleh sistim reward, dan memberi kontribusi pada keefektifan dan keefisienan fungsi organisasi (Organ, 1988 dalam Podsakoff, 2000).

Aspek-aspek dalam OCB menurut Organ (1988) meliputi altruism yaitu perilaku membantu orang lain yang mengalami kesulitan dalam bekerja, conscentiousness yaitu kesungguhan mengerjakan di atas standar minimal yang ditetapkan, sportmanship yaitu menahan diri dari aktivitas-aktivitas mengeluh dan mengumpat terhadap ketidaknyamanan, courtesy yaitu aktif mengumpulkan informasi yang dapat membantu orang lain terhindar dari masalah, civic virtue yaitu partisipasi aktif karyawan dalam kehidupan organisasi (Podsakoff, 2000).

Bernardin menyatakan "performance is defined as the record of outcomes produced on a specific job function or activity during a specific time period (kinerja didefinisikan sebagai catatan mengenai outcome yang dihasilkan dari suatu fungsi kerja atau aktivitas tertentu, selama kurun waktu tertentu)". Kriteria penilaian kinerja yang utama terdiri dari quality yaitu sebuah tingkatan yang menunjukkan bahwa proses atau hasil dari suatu aktivitas mendekati kesempurnaan, yang berkenaan baik kesesuaian terhadap cara yang ideal dalam melaksanakan suatu aktivitas atau tercapainya tujuan aktivitas yang diharapkan. Quantity yaitu jumlah yang dihasilkan, yang dinyatakan dalam satuan mata uang, jumlah unit, atau jumlah dari siklus aktivitas yang diselesaikan. Timelines yaitu sebuah tingkatan yang menunjukkan bahwa suatu aktivitas atau hasil produksi dapat diselesaikan dengan waktu tercepat dari yang ditargetkan dari sudut pandang baik ketika dihubungkan dengan hasil kerja yang lain maupun memaksimalkan waktu yang tersedia untuk aktivitas yang lain. Costeffectiveness yaitu sebuah tingkatan yang menunjukkan penggunaan sumber daya yang dimiliki organisasi (seperti manusia, keuangan, teknologi, material) dimaksimalkan dalam rangka mencapai keuntungan yang tertinggi atau mengurangi kerugian dari masing-masing unit atau contoh penggunaan sumber daya. Need for supervision yaitu sebuah tingkatan yang menunjukkan bahwa pekerja dapat menyelesaikan fungsi tugasnya tanpa harus memerlukan bantuan pengawasan atau memerlukan intervensi atasan untuk mencegah hasil yang tidak sesuai. Interpersonal impact/contextual performance yaitu sebuah tingkatan yang menunjukkan pekerja 
mengembangkan penghargaan terhadap diri (self esteem), niat baik dan kerjasama dengan sesama rekan kerja dan bawahannya (Bernardin, 2010) .

Menurut Cohen dan Vigoda (2000) semakin banyak anggota organisasi menunjukkan OCB maka organisasi akan semakin efektif beroperasi dan semakin sukses untuk meraih tujuantujuannya dan menyelesaikan tantangantantangannya (Shragay, 2011). Organ dan Ryan (1995) menyatakan bahwa kepuasan pegawai, komitmen organisasional, persepsi terhadap keadilan dan persepsi terhadap dukungan pimpinan menjadi faktor-faktor penentu OCB (Podsakoff et al, 2000). Dan dimensi motivasi, kepuasan kerja, dan komitmen organisasional secara jelas berhubungan dengan OCB (Luthans, 2006:251). Kepuasan kerja dan komitmen organisasional berhubungan secara timbal balik atau resiprokal (Huang,2007). Sedangkan kinerja dipengaruhi oleh kepuasan kerja (Rivai, 2011). Hubungan antara komitmen organisasional dan kinerja sangat kuat pada pegawai baru dan akan melemah pada pegawai yang lebih berpengalaman (Robbins, 2011). Individu yang menunjukkan OCB akan menunjukkan kinerja yang lebih baik dan menerima penilaian kinerja yang lebih tinggi. OCB juga berhubungan dengan kelompok dan kinerja organisasi dan efektivitas (Luthans, 2002). Ringkasan penelitian dari dulu sampai sekarang menunjukkan hubungan yang positif antara komitmen organisasional dan hasil yang diinginkan seperti kinerja tinggi, tingkat pergantian karyawan rendah, dan tingkat ketidakhadiran yang rendah. ( Luthans 2006:250)

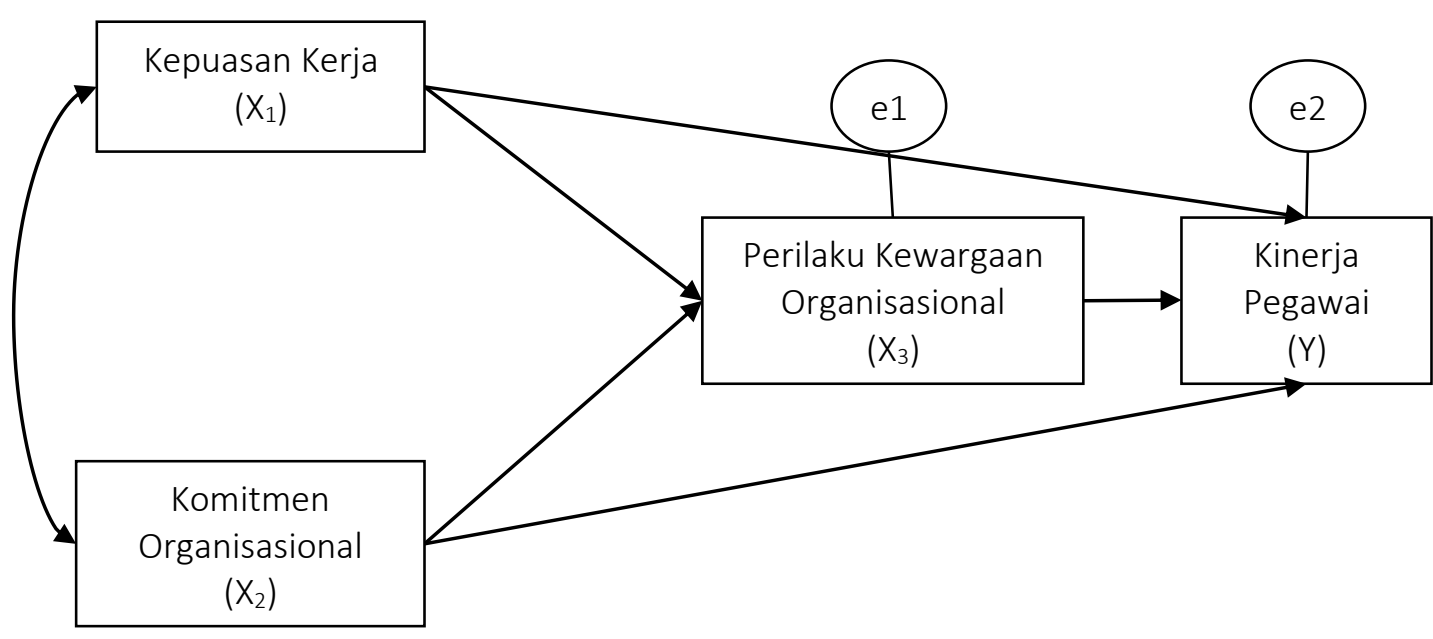

Gambar 1.

Hubungan Antara Variabel Kepuasan Kerja dan Komitmen Organisasional Terhadap Perilaku Kewargaan Organisasional dan Implikisasinya terhadap Kinerja Pegawai Politeknik Komputer Niaga LPKIA

Berdasarkan dari kerangka berfikir penulis memutuskan hipotesis sebagai berikut:

- Hipotesis 1 "Terdapat pengaruh yang positif antara kepuasan kerja terhadap perilaku kewargaan organisasional (OCB)."

- Hipotesis 2 "Terdapat pengaruh yang positif antara komitmen organisasional terhadap perilaku kewargaan organisasional (OCB)."

- Hipotesis 3 "Terdapat pengaruh yang positif antara kepuasan kerja terhadap kinerja pegawai." 
- Hipotesis 4 "Terdapat pengaruh yang positif antara komitmen organisasional terhadap kinerja pegawai."

- Hipotesis 5 "Terdapat pengaruh yang positif antara perilaku kewargaan organisasional (OCB) terhadap kinerja pegawai."

\section{METODE PENELITIAN}

\section{TABEL 1. OPERASIONALISASI VARIABEL PENELITIAN}

\begin{tabular}{|c|c|c|c|c|}
\hline Variabel & Dimensi & Indikator & No Item & Skala \\
\hline \multirow{10}{*}{$\begin{array}{l}\text { Kepuasan Kerja: } \\
\text { merupakan derajat atau } \\
\text { tingkatan perasaan } \\
\text { positif maupun negatif } \\
\text { seorang individu } \\
\text { terhadap pekerjaannya. } \\
\text { (Schermerhorn, } \\
\text { 2005:143). }\end{array}$} & \multirow{3}{*}{$\begin{array}{l}\text { Pekerjaan itu sendiri } \\
\text { (work it self) }\end{array}$} & Tugas yang menarik & $1,2,3$ & Ordinal \\
\hline & & $\begin{array}{l}\text { Kesempatan untuk } \\
\text { belajar }\end{array}$ & 4,5 & Ordinal \\
\hline & & $\begin{array}{c}\text { Kesempatan untuk } \\
\text { menerima tanggung } \\
\text { jawab }\end{array}$ & 6 & Ordinal \\
\hline & \multirow{2}{*}{$\begin{array}{l}\text { Kualitas supervisi } \\
\text { (quality of } \\
\text { supervision) }\end{array}$} & $\begin{array}{c}\text { Kemampuan memberikan } \\
\text { bantuan teknis }\end{array}$ & $7,8,9$ & Ordinal \\
\hline & & $\begin{array}{c}\text { Kemampuan memberikan } \\
\text { dukungan sosial }\end{array}$ & $\begin{array}{c}10,11,12 \\
13\end{array}$ & Ordinal \\
\hline & \multirow{2}{*}{$\begin{array}{l}\text { Hubungan dengan } \\
\text { rekan kerja } \\
\text { (relationships with } \\
\text { co-workers) }\end{array}$} & $\begin{array}{l}\text { Kecakapan teknis rekan } \\
\text { kerja }\end{array}$ & 14,15 & Ordinal \\
\hline & & Dukungan rekan kerja & 16 & Ordinal \\
\hline & $\begin{array}{c}\text { Kesempatan } \\
\text { promosi (promotion } \\
\text { opportunities) }\end{array}$ & $\begin{array}{l}\text { Kesempatan untuk maju } \\
\text { dalam organisasi }\end{array}$ & 17,18 & Ordinal \\
\hline & \multirow[b]{2}{*}{ Gaji/upah (Pay) } & Jumlah gaji yang diterima & 19,20 & Ordinal \\
\hline & & $\begin{array}{l}\text { Keadilan dalam } \\
\text { pemberian gaji }\end{array}$ & 21 & Ordinal \\
\hline \multirow{4}{*}{$\begin{array}{c}\text { Komitmen } \\
\text { Organisasional: } \\
\text { keinginan kuat untuk } \\
\text { tetap sebagai anggota } \\
\text { organisasi tertentu, } \\
\text { keinginan untuk } \\
\text { berusaha keras sesuai } \\
\text { keinginan organisasi, } \\
\text { keyakinan tertentu dan } \\
\text { penerimaan nilai dan }\end{array}$} & \multirow{3}{*}{$\begin{array}{c}\text { Komitmen afektif } \\
\text { (Affective } \\
\text { Commitment) }\end{array}$} & $\begin{array}{l}\text { Keterikatan emosional } \\
\text { terhadap organisasi }\end{array}$ & 22,23 & Ordinal \\
\hline & & $\begin{array}{c}\text { Keberpihakan terhadap } \\
\text { organisasi }\end{array}$ & 24,25 & Ordinal \\
\hline & & $\begin{array}{c}\text { Keterlibatan dalam } \\
\text { organisasi }\end{array}$ & 26 & Ordinal \\
\hline & $\begin{array}{l}\text { Komitmen } \\
\text { keberlanjutan } \\
\text { (Continuance } \\
\text { Commitment) }\end{array}$ & Kerugian bila keluar & 27,28 & Ordinal \\
\hline
\end{tabular}




\begin{tabular}{|c|c|c|c|c|}
\hline $\begin{array}{l}\text { tujuan organisasi . } \\
\text { (Luthans, 2006) }\end{array}$ & $\begin{array}{l}\text { Komitmen normatif } \\
\text { ( Normative } \\
\text { Commitment }\end{array}$ & $\begin{array}{c}\text { Wajib berada di } \\
\text { organisasi karena alasan } \\
\text { moral dan etis }\end{array}$ & 29,30 & Ordinal \\
\hline \multirow{6}{*}{$\begin{array}{l}\text { Perilaku Kewargaan } \\
\text { Organisasional - OCB: } \\
\text { perilaku individu yang } \\
\text { mempunyai kebebasan } \\
\text { untuk memilih, yang } \\
\text { secara tidak langsung } \\
\text { atau secara eksplisit } \\
\text { diakui oleh sistim } \\
\text { reward, dan memberi } \\
\text { kontribusi pada } \\
\text { keefektifan dan } \\
\text { keefisienan fungsi } \\
\text { organisasi. (Organ, 1988 } \\
\text { dalam Podsakoff, 2000) }\end{array}$} & Altruisme (Altruism) & $\begin{array}{c}\text { Membantu orang lain } \\
\text { yang mengalami kesulitan } \\
\text { dalam bekerja }\end{array}$ & $\begin{array}{c}31,32,33 \\
34,35\end{array}$ & Ordinal \\
\hline & $\begin{array}{c}\text { Kesungguhan } \\
\text { (Conscentiousness) }\end{array}$ & $\begin{array}{c}\text { Mengerjakan di atas } \\
\text { standar minimal yang } \\
\text { ditetapkan }\end{array}$ & $\begin{array}{c}36,37,38 \\
39,40\end{array}$ & Ordinal \\
\hline & \multirow{2}{*}{$\begin{array}{c}\text { Sportivitas } \\
\text { (Sportmanship) }\end{array}$} & $\begin{array}{c}\text { Menahan diri dari } \\
\text { mengeluh terhadap } \\
\text { ketidaknyamanan }\end{array}$ & 41,42 & Ordinal \\
\hline & & $\begin{array}{l}\text { Menahan diri dari } \\
\text { mengumpat terhadap } \\
\text { ketidaknyamanan }\end{array}$ & 43 & Ordinal \\
\hline & $\begin{array}{l}\text { Warga yang aktif } \\
\text { (Civic Virtue) }\end{array}$ & $\begin{array}{c}\text { Partisipasi aktif karyawan } \\
\text { dalam kehidupan } \\
\text { organisasi } \\
\end{array}$ & $\begin{array}{l}44,45,46 \\
47,48,49\end{array}$ & Ordinal \\
\hline & Kebaikan (Courtesy) & $\begin{array}{l}\text { Aktif mengumpulkan } \\
\text { informasi yang dapat } \\
\text { membantu orang lain } \\
\text { terhindar dari masalah. }\end{array}$ & 50,51 & Ordinal \\
\hline \multirow{8}{*}{$\begin{array}{c}\text { Kinerja pegawai: } \\
\text { catatan mengenai } \\
\text { outcome yang dihasilkan } \\
\text { dari suatu fungsi kerja } \\
\text { atau aktivitas tertentu, } \\
\text { selama kurun waktu } \\
\text { tertentu (Bernardin, } \\
\text { 2010). }\end{array}$} & \multirow{2}{*}{ Kualitas (Quality) } & $\begin{array}{l}\text { Ketepatan hasil kerja } \\
\text { sesuai dengan prosedur } \\
\text { kerja yang ditetapkan }\end{array}$ & 52 & Ordinal \\
\hline & & $\begin{array}{c}\text { Kualitas hasil kerja sesuai } \\
\text { dengan standar yang } \\
\text { ditetapkan. }\end{array}$ & 53 & Ordinal \\
\hline & Jumlah (Quantity) & $\begin{array}{c}\text { Jumlah hasil pekerjaan } \\
\text { atau aktivitas yang telah } \\
\text { diselesaikan. }\end{array}$ & 54 & Ordinal \\
\hline & $\begin{array}{l}\text { Batasan waktu } \\
\text { (Timelines) }\end{array}$ & $\begin{array}{c}\text { Ketepatan penyelesaian } \\
\text { tugas sesuai dengan } \\
\text { jadwal yang telah } \\
\text { ditetapkan. }\end{array}$ & 55 & Ordinal \\
\hline & \multirow{2}{*}{$\begin{array}{c}\text { Efektivitas sumber } \\
\text { daya (Cost- } \\
\text { effectiveness) }\end{array}$} & $\begin{array}{c}\text { Menggunakan sumber } \\
\text { daya dan fasilitas yang } \\
\text { ada dengan baik dalam } \\
\text { bekerja }\end{array}$ & 56 & Ordinal \\
\hline & & $\begin{array}{c}\text { Kreativitas mencari } \\
\text { sumber daya alternatif }\end{array}$ & 57 & Ordinal \\
\hline & \multirow{2}{*}{$\begin{array}{c}\text { Kebutuhan } \\
\text { pengawasan (Need } \\
\text { for supervision) }\end{array}$} & $\begin{array}{c}\text { Dapat bekerja mandiri } \\
\text { tanpa bantuan atau } \\
\text { keterlibatan atasan }\end{array}$ & 58 & Ordinal \\
\hline & & $\begin{array}{c}\text { Dapat bekerja mandiri } \\
\text { tanpa pengawasan } \\
\text { atasan }\end{array}$ & 59 & Ordinal \\
\hline
\end{tabular}




\begin{tabular}{|c|c|c|c|c|}
\hline & $\begin{array}{l}\text { Hubungan dengan } \\
\text { orang lain } \\
\text { (Interpersonal }\end{array}$ & $\begin{array}{c}\text { Kemampuan } \\
\text { bekerjasama dengan baik } \\
\text { dengan karyawan lain } \\
\text { saat bekerja }\end{array}$ & 60 & Ordinal \\
\hline & $\begin{array}{c}\text { impact/contextual } \\
\text { performance) }\end{array}$ & $\begin{array}{l}\text { Kesediaan mengerjakan } \\
\text { tugas diluar yang menjadi } \\
\text { tanggung jawabnya. }\end{array}$ & 61 & Ordinal \\
\hline
\end{tabular}

\section{Sumber Data Penelitian}

Sumber data primer merupakan sumber data dimana data tersebut diperoleh secara langsung dari lapangan melalui penyebaran angket.Sumber-sumber sekunder dalam penelitian ini diambil dari sumber-sumber yang lain, yaitu laporan ilmiah, data dan dokumendokumen perusahaan yang memiliki keterkaitan dan sekaligus mendukung dalam penelitian ini.

\section{Teknik Pengumpulan Data}

Teknik pengumpulan data yang digunakan dalam penelitian ini adalah menggunakan angket berupa kuesioner. Skala penilaian yang digunakan yaitu skala Likert yang dirancang untuk mengukur sikap. Skala ini menguji apakah responden Sangat Tidak Setuju yang diwakili dengan angka 1, Tidak Setuju yang diwakili angka 2, Ragu-ragu yang diwakili angka 3, Setuju yang diwakili angka 4 dan Sangat Setuju yang diwakili angka 5.

Sebelum angket digunakan dalam mengumpulkan data yang sebenarnya, dilakukan uji validitas dan uji reliabilitas angket guna mengetahui kekurangan-kekurangan pada item angket, berkaitan dengan redaksi, alternatif jawaban maupun maksud yang terkandung dalam pernyataan item angket tersebut.

Observasi yaitu melakukan pengamatan langsung dan pencatatan terhadap objek yang diteliti. Data tersebut berupa pendapat para pegawai mengenai kepuasan kerja, komitmen organisasional, perilaku kewargaan organisasional dan kinerja pegawai.

\section{Populasi dan Sampel}

Responden dalam penelitian ini adalah pegawai administrasi Politeknik Komputer Niaga LPKIA. Dikarenakan jumlah responden kurang dari 100 orang, maka penelitian ini menggunakan total sampling dengan meneliti keseluruhan staf PKN LPKIA. Populasi penelitian ini adalah staf operasional PKN LPKIA yang yang berjumlah 40 orang.

\section{Pengujian Hipotesis}

Multivariate statistic analysis berkaitan dengan metode-metode statistik yang secara bersama-sama (simultan) melakukan analisis terhadap lebih dari dua variabel. Multivariate statistic analysis untuk menjawab topik utama di dalam penelitian yaitu relasi di antara Kepuasan kerja (X1) dan Komitmen Organisasional (X2) dalam Perilaku Kewargaan Organisasional (X3) dan Kinerja Pegawai (Y), menggunakan model partial least square (PLS).

PLS merupakan model persamaan struktural (structural equation modelling atau SEM) berbasis variance atau component untuk menganalisis hubungan di antara satu variabel yang didasarkan dugaan bahwa hubungan antar variabel yang ditetapkan mengacu serta mempertimbangan dasar pengetahuan (teori) yang telah jelas, dimana setiap variabel diasumsikan dapat mewakili konsep teoritis yang direpresentasikan dalam bentuk variabel laten. 
4. Hasil Pengujian dan Pembahasan

Pengujian terhadap model struktural dilakukan dengan uji signifikansi masing-masing parameter dengan cara membandingkan nilai tstatistik dengan t tabel (pada taraf signifikansi $5 \%$ ), selanjutnya melihat nilai R-square yang merupakan uji goodness-fit model.

Tabel 2 Nilai Signifikansi (t-statistik ) dan R-square

\begin{tabular}{|c|c|c|c|}
\hline & $\boldsymbol{\lambda}$ & $\mathbf{T}$ & R-square \\
\hline $\mathrm{KK}(\mathrm{X} 1)->\mathrm{PKO}(\mathrm{X} 3)$ & 0,262 & 1,422 & \multirow{2}{*}{0,289} \\
\cline { 1 - 3 } $\mathrm{KO}(\mathrm{X} 2)->\mathrm{PKO}(\mathrm{X} 3)$ & 0,333 & 2,257 & \\
\hline $\mathrm{KK}(\mathrm{X} 1)->\mathrm{KP}(\mathrm{Y})$ & $-0,008$ & 0,040 & \multirow{2}{*}{0,522} \\
\cline { 1 - 3 } $\mathrm{KO}(\mathrm{X} 2)->\mathrm{KP}(\mathrm{Y})$ & 0,101 & 0,713 & \multirow{2}{*}{0,522} \\
\cline { 1 - 3 } $\mathrm{PKO}(\mathrm{X} 3)->\mathrm{KP}(\mathrm{Y})$ & 0,672 & 9,650 & \\
\hline
\end{tabular}

Persamaan struktural berdasarkan tabel di atas adalah sebagai berikut:

$$
\begin{aligned}
& \text { PKO }=0,262 K K+0,333 K O+\varepsilon 1 \\
& K P=-0,008 K K+0,101 K O+0,672 P K O+\varepsilon 2
\end{aligned}
$$

Berdasarkan tabel dan persamaan di atas, koefisien parameter kepuasan kerja terhadap perilaku kewargaan organisasional adalah sebesar 0,262 dengan nilai t statistik sebesar 1,422. Karena nilai t statistik lebih kecil dari t tabel (t tabel dengan signifikansi 5\% sebesar 1,96) maka memberikan kesimpulan yang tidak signifikan artinya tidak terdapat pengaruh positif dari kepuasan kerja terhadap perilaku kewargaan organisasional.

Koefisien parameter komitmen organisasional terhadap perilaku kewargaan organisasional adalah sebesar 0,333 dengan nilai $\mathrm{t}$ statistik sebesar 2,257. Karena nilai $\mathrm{t}$ statistik lebih besar dari t tabel (t tabel dengan signifikansi 5\% sebesar 1,96) maka memberikan kesimpulan yang signifikan artinya terdapat pengaruh positif dari komitmen organisasional terhadap perilaku kewargaan organisasional.
Koefisien parameter kepuasan kerja terhadap kinerja pegawai adalah sebesar -0,008 dengan nilai t statistik sebesar 0,040. Karena nilai t statistik lebih kecil dari t tabel (t tabel dengan signifikansi $5 \%$ sebesar 1,96) maka memberikan kesimpulan yang tidak signifikan artinya tidak terdapat pengaruh positif dari kepuasan kerja terhadap kinerja pegawai.

Koefisien parameter komitmen organisasional terhadap kinerja pegawai adalah sebesar 0,101 dengan nilai t statistik sebesar 0,713 . Karena nilai t statistik lebih kecil dari $t$ tabel (t tabel dengan signifikansi 5\% sebesar 1,96) maka memberikan kesimpulan yang tidak signifikan artinya tidak terdapat pengaruh positif dari komitmen organisasional terhadap kinerja pegawai.

Koefisien parameter perilaku kewargaan organisasional terhadap kinerja pegawai adalah sebesar 0,672. dengan nilai t statistik sebesar 9,650 . Karena nilai t statistik lebih besar dari t tabel (t tabel dengan signifikansi 5\% sebesar 1,96) maka memberikan kesimpulan yang signifikan artinya terdapat pengaruh positif dari perilaku kewargaan organisasional terhadap kinerja pegawai.

Nilai $r$ square sebesar 0,289 menunjukkan bahwa kepuasan kerja dan komitmen organisasional mampu menjelaskan variabel konstruk perilaku kewargaan organisasional sebesar 28,9\%, sisanya sebesar 71,1\% diterangkan oleh konstruk lainnya yang tidak dihipotesiskan dalam model.

Nilai $r$ square sebesar 0,522 menunjukkan bahwa kepuasan kerja, komitmen organisasional dan perilaku kewargaan organisasional mampu menjelaskan variabel konstruk kinerja pegawai sebesar 52,2\%, sisanya sebesar 47,8\% diterangkan oleh konstruk lainnya yang tidak dihipotesiskan dalam model.

Besarnya pengaruh langsung, pengaruh tidak langsung dan pengaruh total dapat dilihat pada tabel berikut: 
Tabel 3. Pengaruh Langsung, Tidak langsung

\begin{tabular}{|c|c|c|c|}
\hline Pengaruh & Langsung & Tidak langsung Melalui $\mathbf{X}_{\mathbf{3}}$ & Total \\
\hline $\mathrm{KK}(\mathrm{X} 1)->\mathrm{PKO}(\mathrm{X} 3)$ & 0,262 & - & 0,262 \\
\hline $\mathrm{KO}(\mathrm{X} 2)->\mathrm{PKO}(\mathrm{X} 3)$ & 0,333 & - & 0,333 \\
\hline $\mathrm{KK}(\mathrm{X} 1)->\mathrm{KP}(\mathrm{Y})$ & $-0,008$ & 0,176 & 0,168 \\
\hline $\mathrm{KO}(\mathrm{X} 2)->\mathrm{KP}(\mathrm{Y})$ & 0,101 & 0,224 & 0,325 \\
\hline $\mathrm{PKO}(\mathrm{X} 3)->\mathrm{KP}(\mathrm{Y})$ & 0,672 & - & 0,672 \\
\hline
\end{tabular}

Berdasarkan tabel di atas diperoleh kesimpulan sebagai berikut:

1. Pengaruh langsung kepuasan kerja terhadap perilaku kewargaan organisasional adalah $(0,262)^{2}=6,86 \%$.

2. Pengaruh langsung komitmen organisasional terhadap perilaku kewargaan organisasional adalah $(0,333)^{2}=$ $11,09 \%$.

3. Pengaruh langsung perilaku kewargaan organisasional terhadap kinerja pegawai adalah $(0,672)^{2}=45,15 \%$.

4. Pengaruh langsung kepuasan kerja terhadap kinerja pegawai adalah $(-0,008)^{2}=$ 0,0064\%, sedangkan pengaruh tidak langsung kepuasan kerja terhadap kinerja pegawai melalui perilaku kewargaan organisasional adalah $(0,176)^{2}=3,09 \%$. Sehingga pengaruh total kepuasan kerja terhadap kinerja pegawai adalah $(0,168)^{2}=$ $2,82 \%$.

5. Pengaruh langsung komitmen organisasional terhadap kinerja pegawai adalah $\quad(0,101)^{2}=1,02 \%$, sedangkan pengaruh tidak langsung komitmen organisasional terhadap kinerja pegawai melalui perilaku kewargaan organisasional adalah $(0,224)^{2}=5,02 \%$. Sehingga pengaruh total komitmen organisasional terhadap kinerja pegawai adalah $(0,325)^{2}=10,56 \%$.

\section{PEMBAHASAN}

Temuan penelitian menunjukkan koefisien parameter kepuasan kerja terhadap perilaku kewargaan organisasional adalah sebesar 0,262 sehingga besarnya pengaruh langsung adalah 6,86\%. Sedangkan nilai t statistik sebesar 1,422. Karena nilai t statistik lebih kecil dari t tabel ( $\mathrm{t}$ tabel dengan signifikansi 5\% sebesar 1,96) maka memberikan kesimpulan yang tidak signifikan artinya tidak terdapat pengaruh positif dari kepuasan kerja terhadap perilaku kewargaan organisasional. Hal ini berarti bahwa kepuasan kerja tidak berkontribusi yang positif dan signifikan terhadap perilaku kewargaan organisasional. Artinya tinggi rendahnya perilaku kewargaan organisasional tidak dijelaskan oleh kepuasan kerja pegawai.

Temuan penelitian ini diperkuat dengan pernyataan yang dikemukakan oleh Robbins dan Jugde (2008:114) bahwa kepuasan kerja tidak berkaitan dengan perilaku kewargaan organisasional ketika keadilan diperhitungkan. Pada dasarnya, kepuasan kerja bergantung pada gambaran-gambaran mengenai hasil, perlakuan, dan prosedur-prosedur yang adil. Apabila pegawai tidak merasa bahwa pengawas, prosedur organisasi, atau kebijaksanaan bayaran adil, kepuasan kerja pegawai cenderung menurun secara signifikan. Namun, ketika pegawai merasa bahwa proses dan hasil-hasil organisasional tersebut adil, berkembanglah 
rasa percaya. Selain itu, ketika pegawai memercayai pemberi kerja, pegawai lebih bersedia untuk terlibat secara sukarela dalam perilaku-perilaku yang melebihi persyaratan kerja formal pegawai.

Hasil penelitian Steve Williams, Richards Pitre dan Mohammad Zainuba (2002) menunjukkan bahwa perilaku kewargaan organisasional akan meningkat bila persepsi pegawai terhadap perlakuan adil dari atasan semakin positif. Perlakuan atasan menjadi lebih penting dari imbalan atau keadilan dalam sistem organisasi. Ketika anggaran untuk imbalan dan kebijakan organisasi diluar jangkauan para supervisor, perlakuan atasan terhadap bawahan dan kemampuan untuk menunjukkan kesungguhan memperlakukan adil berada dalam jangkauannya.

Koefisien parameter komitmen organisasional terhadap perilaku kewargaan organisasional adalah sebesar 0,333 dengan nilai $\mathrm{t}$ statistik sebesar 2,257. Karena nilai $\mathrm{t}$ statistik lebih besar dari t tabel (t tabel dengan signifikansi 5\% sebesar 1,96) maka memberikan kesimpulan yang signifikan artinya terdapat pengaruh positif dari komitmen organisasional terhadap perilaku kewargaan organisasional. Temuan penelitian ini menunjukkan bahwa komitmen organisasional berkontribusi terhadap perilaku kewargaan organisasional. Temuan ini diperkuat oleh pernyataan Organ dan Ryan (1995) dalam Podsakoff (2000) yang menyatakan bahwa komitmen organisasional menjadi penentu perilaku kewargaan organisasional. Demikian pula pada Luthans (2006:251) disebutkan pula bahwa dimensi komitmen organisasional secara jelas berhubungan dengan perilaku kewargaan organisasional.

Koefisien parameter kepuasan kerja terhadap kinerja pegawai adalah sebesar -0,008 dengan nilai t statistik sebesar 0,040. Pengaruh langsung kepuasan kerja terhadap kinerja pegawai adalah $0,0064 \%$, sedangkan pengaruh tidak langsung kepuasan kerja terhadap kinerja pegawai melalui perilaku kewargaan organisasional adalah 3,09\%. Sehingga pengaruh total kepuasan kerja terhadap kinerja pegawai adalah $2,82 \%$. Karena nilai t statistik lebih kecil dari $t$ tabel ( $t$ tabel dengan signifikansi 5\% sebesar 1,96) maka memberikan kesimpulan yang tidak signifikan artinya tidak terdapat pengaruh positif dari kepuasan kerja terhadap kinerja pegawai. Temuan penelitian ini menunjukkan bahwa kepuasan kerja tidak berkontribusi yang positif dan signifikan terhadap kinerja pegawai. Artinya tinggi rendahnya kinerja pegawai tidak dijelaskan oleh kepuasan kerja pegawai. Temuan penelitian ini diperkuat dengan teori dua faktor (two factor theory) disebut juga teori motivasi higiene (motivation-Hygiene theory) yang dikemukakan oleh Frederick Herzberg. Dengan keyakinan bahwa hubungan seorang individu dengan pekerjaan adalah mendasar dan bahwa sikap seseorang terhadap pekerjaan bisa dengan sangat baik menentukan keberhasilan dan kegagalan.

Koefisien parameter komitmen organisasional terhadap kinerja pegawai adalah sebesar 0,101 dengan nilai t statistik sebesar 0,713 . Karena nilai $t$ statistik lebih kecil dari $t$ tabel (t tabel dengan signifikansi 5\% sebesar 1,96) maka memberikan kesimpulan yang tidak signifikan artinya tidak terdapat pengaruh positif dari komitmen organisasional terhadap kinerja pegawai. Pengaruh langsung komitmen organisasional terhadap kinerja pegawai adalah $1,02 \%$, sedangkan pengaruh tidak langsung komitmen organisasional terhadap kinerja pegawai melalui perilaku kewargaan organisasional adalah 5,02\%. Sehingga pengaruh total komitmen organisasional terhadap kinerja pegawai adalah 10,56\%. Temuan penelitian ini menunjukkan bahwa komitmen organisasional tidak berkontribusi yang positif dan signifikan terhadap kinerja pegawai. Artinya tinggi rendahnya kinerja 
pegawai tidak dijelaskan oleh komitmen organisasional. Temuan penelitian ini diperkuat dengan pernyataan yang dikemukakan oleh Armstrong \& Baron dalam Sedarmayanti menjelaskan faktor yang mempengaruhi kinerja antara lain (a) personal factors: ditunjukkan tingkat keterampilan, kompetensi yang dimiliki, motivasi dan komitmen individu. (b) leadership factor: ditentukan kualitas dorongan bimbingan, dan dukungan yang dilakukan manajer dan team leader. (c) team factors: ditunjukkan kualitas dukungan yang diberikan oleh rekan sekerja. (d) system factors: ditunjukkan adanya sistem kerja dan fasilitas yang diberikan organisasi. (e) contextual/situational factors: ditunjukkan tingginya tingkat tekanan lingkungan internal dan eksternal (Sedarmayanti, 2011:223). Sebuah studi menemukan hubungan yang lebih kuat antara komitmen organisasional dan kinerja untuk orang dengan kebutuhan finansial rendah daripada orang dengan kebutuhan finansial tinggi. Studi lain menunjukkan bahwa komitmen pada penyelia lebih berhubungan dengan kinerja daripada komitmen pada organisasi. (Luthans 2006:250)

Koefisien parameter perilaku kewargaan organisasional terhadap kinerja pegawai adalah sebesar 0,672. dengan nilai $t$ statistik sebesar 9,650 . Karena nilai t statistik lebih besar dari t tabel (t tabel dengan signifikansi 5\% sebesar 1,96) maka memberikan kesimpulan yang signifikan artinya terdapat pengaruh positif dari perilaku kewargaan organisasional terhadap kinerja pegawai. Temuan penelitian menunjukkan bahwa komitmen organisasional berkontribusi terhadap perilaku kewargaan organisasional. Besarnya kontribusi perilaku kewargaan organisasional yang secara langsung berkontribusi terhadap kinerja pegawai sebesar $45,15 \%$. Oleh karena itu komitmen organisasional perlu ditingkatkan agar perilaku kewargaan organisasional juga meningkat. Temuan penelitian ini diperkuat dengan pernyataan yang dikemukakan oleh Podsakoff et al, 2000 bahwa perilaku kewargaan organisasional meningkatkan stabilitas kinerja organisasi. Membantu tugas karyawan yang tidak hadir di tempat kerja atau yang mempunyai beban kerja berat akan meningkatkan stabilitas dari kinerja unit kerja. Karyawan yang conscientious cenderung mempertahankan tingkat kinerja yang tinggi secara konsisten, sehingga mengurangi variabilitas pada kinerja unit kerja.

Nilai $r$ square sebesar 0,289 menunjukkan bahwa kepuasan kerja dan komitmen organisasional mampu menjelaskan variabel konstruk perilaku kewargaan organisasional sebesar 28,9\%, sisanya sebesar $71,1 \%$ diterangkan oleh konstruk lainnya yang tidak dihipotesiskan dalam model. Hasil ini menunjukkan bahwa kepuasan kerja dan komitmen organisasional hanya memberikan pengaruh yang kecil terhadap perilaku kewargaan organisasional, terdapat hal-hal lain yang mempengaruhi tinggi rendahnya perilaku kewargaan organisasional seseorang. Penelitian yang dilaksanakan Podsakoff menunjukkan bahwa anteseden sikap kerja, variabel tugas, ragam tipe perilaku pemimpin lebih mempengaruhi perilaku kewargaan organisasional dibandingkan anteseden yang lain. Pada penelitian tersebut juga dijelaskan bahwa kepemimpinan berperan sangat penting dalam mempengaruhi perlaku kewargaan organisasional.

Temuan penelitian menunjukkan bahwa kepuasan kerja, komitmen organisasional dan perilaku kewargaan organisasional mampu menjelaskan variabel konstruk kinerja pegawai sebesar 52,2\%, sisanya sebesar 47,8\% diterangkan oleh konstruk lainnya yang tidak dihipotesiskan dalam model. Hasil ini menunjukkan bahwa kepuasan kerja, komitmen organisasional dan perilaku kewargaan 
organisasional memiliki pengaruh yang besar terhadap kinerja seseorang.

\section{KESIMPULAN DAN SARAN}

\section{KESIMPULAN}

1. Kepuasan kerja yang diukur oleh perilaku kewargaan organisasional tidak berkontribusi yang positif dan signifikan terhadap tinggi rendahnya perilaku kewargaan organisasional, artinya bahwa tinggi rendahnya perilaku kewargaan organisasional tidak dapat dijelaskan oleh kepuasan kerja pegawai. Hal ini dapat terjadi ketika faktor keadilan diperhitungkan.

2. Komitmen organisasional yang diukur oleh perilaku kewargaan organisasional memiliki kontribusi yang positif dan signifikan terhadap tinggi rendahnya perilaku kewargaan organisasional. Dengan demikian tinggi rendahnya perilaku kewargaan organisasional dapat dijelaskan oleh komitmen organisasional.

3. Kepuasan kerja yang diukur oleh kinerja pegawai tidak berkontribusi yang positif dan signifikan terhadap tinggi rendahnya kinerja pegawai, artinya tinggi rendahnya kinerja pegawai tidak dapat dijelaskan oleh kepuasan kerja pegawai. Hal ini menunjukkan bahwa dibutuhkan faktor lain yang dapat meningkatkan kinerja pegawai selain faktor-faktor higiene dalam kepuasan kerja yaitu faktor-faktor yang memotivasi pegawai.

4. Komitmen organisasional yang diukur oleh kinerja pegawai tidak berkontribusi yang positif dan signifikan terhadap kinerja pegawai. Hal ini berarti tinggi rendahnya kinerja pegawai tidak dapat dijelaskan oleh komitmen organisasional. Hubungan yang lebih kuat antara komitmen organisasional dan kinerja untuk orang dengan kebutuhan finansial yang rendah.

5. Perilaku kewargaan organisasional yang diukur oleh kinerja pegawai memiliki kontribusi yang positif dan signifikan terhadap tinggi rendahnya kinerja pegawai. Dengan demikian tinggi rendahnya kinerja dapat dijelaskan oleh perilaku kewargaan organisasional hal ini disebabkan karena perilaku kewargaan organisasional dapat meningkatkan stabilitas kinerja organisasi

\section{SARAN}

1. Perlunya usaha-usaha peningkatan kepercayaan pegawai terhadap atasan maupun institusi, seperti peningkatan kualitas komunikasi kepemimpinan, keadilan dan transparansi dalam proses dan hasil organisasi.

2. Institusi memberikan peluang promosi, peluang pengembangan diri, penghargaan atau apresiasi, pemberian tanggung jawab, dan tantangan-tantangan untuk meningkatkan motivasi pegawai.

3. Bagi akademisi atau peneliti lain disarankan untuk melakukan penelitian lanjutan dengan menambahkan variabel lain dalam penelitian sehingga dapat diketahui variabel atau faktor lain selain kepuasan kerja dan komitmen organisasional yang dapat meningkatkan perilaku kewargaan organisasional. Selain itu disarankan untuk melakukan penelitian dengan ruang lingkup atau objek yang lebih luas menjadi keefektifan organisasi yaitu dengan membandingkan keefektifan satu organisasi dengan organisasi lain yang sejenis.

\section{DAFTAR PUSTAKA}

\section{Buku}


Carnegie, Dale \& Associates. 2011. How to Win friends \& Influence People in the Digital Age. Jakarta: Gramedia Pustaka Utama

Ghozali, Imam. 2008. Structural Equation Modeling Metode Alternatif dengan Partial Least Square (PLS). Semarang:Badan Penerbit-Undip

Ivancevich, John M. 2005. Perilaku dan Manajemen Organisasi. Jakarta:Erlangga (alih bahasa Dharma Yuwono S.Psi)

Luthans, Fred. 2006. Perilaku Organisasi. Yogyakarta: Andi (alih bahasa Vivi Andhika Yuwono)

Luthans, Fred. 2002. Organizational Behavior. New York:McGraw-Hill

Rivai, Veithzal. 2010. Manajemen Sumber Daya Manusia untuk Perusahaan. Jakarta:Raja Grafino Persada

Rivai, Veithzal et. al. 2011. Corporate Performance Management. Bogor:Ghalia Indonesia

Robbins, Stephen. 2008. Perilaku Organisasi. Jakarta: Salemba Empat (alih bahasa Diana Angelica dkk)

Robbins, Stephen P. 2011. Organizational Behavior. London:Pearson Education

Riduwan.2007. Cara Menggunakan dan Memaknai Analisis Jalur (Path Analysis). Bandung:Alfabeta

Schermerhorn, John. 2005. Organizational Behavior. John Wiley \& Sons

Sedarmayanti. 2007. Manajemen Sumber Daya Manusia. Bandung:Refika Aditama

Sedarmayanti. 2011. Membangun dan Mengembangkan Kepemimpinan serta Meningkatkan Kinerja untuk Meraih Keberhasilan. Bandung:Refika Aditama
Sugiama, Gima. 2008. Metode Riset Bisnis dan Manajemen. Bandung:Guardaya Intimarta

Sugiyono. 2012. Metode Penelitian Bisnis. Bandung:Alfabeta

Sugiyono. 2012. Statistika untuk Penelitian . Bandung:Alfabeta

Yamin, Sofyan. 2011. Generasi Baru Mengolah Data Penelitian dengan Partial Least Square Path Modeling. Jakarta:Penerbit Salemba Infotek

\section{Jurnal}

Chen, Chien-Cheng. 2009. The Mediating Role of Job Involvement in the Relationship Between Job Characteristics and Organizational Citizenship Behavior. The Journal of Social Psychology

Chiu, Su-Fen \& Chen, Hsiao-Lan. 2005. Relationship Between Job Characteristics and Organizational Citizenship Behavior: The meditational Role of Job Satisfaction. Journal of Social Behavior and Personality

Huang, Tung Chun \& Hsiao, Wan Jung . 2007. The Causal Relationship Between Job Satisfaction and Organizational Commitment. ProQuest Sociology

Kandlousi, Nader Sheykh Al Eslami. 2010. Organizational Citizenship Behavior in Concern of Communication Satisfaction: The Role of the Formal and Informal Communication. International Journal of Business and Management

Podsakoff, Philip M et al. 2000. Organizational Citizenship Behaviors: A critical Review of the Theoretical and Empirical Literature and Suggestions for Future Research. Journal of Management 
Shragay, Dina \& Tziner, Aharon . 2011. The Generational Effect on the Relationship between Job Involvement, Work Satisfaction, and Organizational Citizenship Behavior. Madrid:the Colegio Oficial de Psicologos de Madrid. Vol 27

Williams, Steve et al. 2002. Justice and Organizational Citizenship Behavior Intentions:Fair Rewards Versus Fair Treatment. The Journal of Social Psychology

\section{Tesis}

Alfina, Debi. 2010. Pengaruh Penempatan pegawai dan kepuasan kerja terhadap komitmen organisasional pada PT. Telkom Divre III. Tesis

Dakhi, Mayasari. 2009. Pengaruh Kepuasan Kerja dan Komitmen Organisasional terhadap hasil kerja Salesman DBSP di Jaringan PT. Daya Adira Mustika Bandung. Tesis

Hasdhiananto, Riko. 2008. Pengaruh Outsourcing terhadap Organizational Citizenship Behaviour pada Teller Outsource PT. Bank NISP, Tbk di Bandung.Tesis

Marinda, Vina Silviani. 2012. Pengaruh Kepemimpinan Transformasional dan Employee Engagement terhadap Organizational Citizenship Behavior (OCB) serta dampaknya terhadap keefektifan divisi di PT. Industri Telekomunikasi Indonesia (persero). Tesis

Ricardo P. 2012. Pengaruh Komitmen Organisasional dan Iklim Organisasi terhadap Organizational Citizenship Behavior (OCB) Pada Tenaga Perawat di RS. Pelni Jakarta. Tesis

Setiawan, Irwan. 2012. Pengaruh Kepuasan Kerja dan Komitmen Organisasional terhadap turnover intentions karyawan Bandung TV. Tesis

\section{Majalah}

2012. Mix Marketing Communications. Edisi 06/IX/Juni. Jakarta:SWA Media Investindo 